\title{
Antioxidant and Antimicrobial Activities of Aqueous Extract of the Yellow and White Sweet Spanish onion (Allium cepa L.) in Isfahan
}

\author{
Mahshid Sadeghian ${ }^{1}$, Niloufar Mardani ${ }^{1}$, Mahshid Jahadi ${ }^{1 *}$, Kourosh Keighobadi ${ }^{2}$ \\ 1-Department of Food Science and Technology, Faculty of Agriculture, Isfahan (Khorasgan) Branch, Islamic Azad University, Isfahan, Iran. \\ 2-Plant Improvement and Seed Production Research Center, Isfahan (Khorasgan) Branch, Islamic Azad University, Isfahan, Iran
}

\section{A B S T R A C T}

Background and Objectives: Onion (Allium cepa L.) possesses aromas and flavours, which have made them one of important ingredients of food. In addition, recent publications have reported that onion and its extract have many biological properties such as antimicrobial and antioxidant. Yellow and White Sweet Spanish onions belonging to Amaryllidaceae, are cultivated all over Iran as a condiment, vegetable, and medicinal herbs. In present study, the antioxidant and antimicrobial properties of outer and inner layers were investigated in two hybrid onion bulbs; Yellow and White Sweet Spanish.

Materials and Methods: Cultivation of plant material consisting two cultivars was performed in Isfahan experimental farm $32^{\circ} 38^{\prime} 27.6^{\prime \prime} \mathrm{N}, 51^{\circ} 46^{\prime} 50.3^{\prime \prime} \mathrm{E}$, Iran. In order to assess of sample antioxidant capacity, total phenolic, and total flavonoid contents were estimated for the various fractions. In vitro antioxidant potential of scales onion extracts was evaluated using the scavenging activity for DPPH. Furthermore, this extract was investigated for its ability to provide protection from DNA damage. Disk diffusion and micro-well dilution as some antimicrobial properties of phytochemicals extracted from onion layers were evaluated against seven bacteria and four fungi.

Results: Evaluation results of onion extract biological properties showed that aqueous extract of outer layer had the highest antioxidant activity comparison inner layers. However, extract from Yellow Sweet Spanish onion had more phenolic, flavonoid, radical scavenging activities on DPPH. Thereupon, aqueous extract from outer layers of Yellow Sweet Spanish extract showed the most ability to protection against DNA damage caused by reactive oxygen species. Extracts of inner layers of Yellow Sweet Spanish had more inhibition zone and lower MIC and MMC, for all microorganisms.

Conclusions: This study showed that aqueous extract of outer and inner layers of both onion lumps (Yellow and White Sweet Spanish) had antioxidant activity and inner layers of extract had antimicrobial activity. It should be noted that extract of outer layer onions had the highest antioxidant properties but no antimicrobial properties. Therefore, the aqueous extract of Yellow and White Sweet Spanish onions might be a valuable food additive and can be used as natural antimicrobial and antioxidant additives for incorporating in various food products.

Keywords: Free radical, Medicinal herb, Onion bulb, Pharmacological properties

\section{Introduction}

The genus Allium, belonging to the family Liliaceae, is cultivated worldwide as a condiment, vegetable, and medicinal herb with various applications. In traditional and ancient medicine, onion (Allium cepa L.) as the most important species of this genus has been used as an herbal drug for the treatment of various ailments. Edible onions are one of the oldest cultivated plants, used worldwide as both vegetables and flavouring $(1,2,3)$. Despite to necessary of oxygen as an essential chemical element in the

metabolism of aerobic organisms, it may trigger unfavorable reactions. Reactive oxygen species (ROS) including free radicals are by-production of the normal cellular energy production and functional activities (4). However, if ROS levels increase intensely, it can damage cellular biomolecules including DNA, RNA, lipid, and proteins, resulting in several common health problems (5). Furthermore, this increasing is not only associated with the normal metabolic processes in the human body as 
endogenous sources, but can also be due to environmental factors as exogenous sources (4). When higher production of ROS in relation to removal by antioxidant defenses as biological system occurs, it is called oxidative stress. These defenses may protect cells by a variety of mechanisms (3). In other words, the main characteristics of an antioxidant is its ability to trap free radicals and can be broadly defined as any substance that delay or inhibits oxidative damage to a target molecule (6). Plants play a significant role in supplying food for humans. Medicinal and aromatic plants have played a critical role as therapeutic agents for a long time and thus hold great value (7). The results of several studies on pharmacological and biological properties of these plants declared that onion is a rich source of nutrients that are effective for treating a large number of diseases including cancer, coronary heart, blood transfusion, diabetes type II, blood pressure, cataract and gastrointestinal disorders (8). Due on the desirable and side effects arisen from the consumption of artificial chemical compounds, the essential oil of onion shows a moderate antimicrobial activity against referenced strains and also possess an interesting antioxidant activity (9). Common onion as oldest cultivated vegetable and flavouring plants is known to contain sulphur amino acid together with many vitamins and minerals. Despite to predominant use of this plants as food, a wide range of beneficial effects have also been proved (3). In recent times, great tendency has been focused on using natural antioxidants and antimicrobial compounds. Main natural compounds are essential oils derived from plants have been used in different food industry. The most important characteristics of these components as edible additives in food packaging are to minimize or prevent the photogenic microbe's growth and /or delay the phenomenon of lipid oxidation in foods (9). Onion is rich in sulfur components, thiosulfinates, and so on, which cause the odor and flavors of this plant. Based on several assessments, these attributes related to extracted components and the impacts on human health have been proven (10). Onions with antimicrobial properties exhibited a wide range of organosulfur compounds as antioxidant agent. These components also consist of polyphenols, anthocyanin, flavonoids, quercetin, kaempherol, and glycosides which act as antioxidant compounds $(11,1)$. The tunic layer is a waste produced during onion bulb processing. Recent studies have reported that it contains large amounts of quercetin, quercetin glycoside and other oxidative compounds, which have plays vital oxidative role in against the peroxidation of the non-enzymatic lipoenzymes of low density proteins (5). The present report is an attempt to assay aqueous extract of the outer and inner layers in two hybrid onion bulbs (Yellow and White Sweet Spanish onion bulbs) which is commonly cultivated and used in Isfahan, Iran. The main aim of this study is to investigate and develop experiments for onion antimicrobial and antioxidant characteristics.

\section{Materials and Methods}

Chemicals and materials: Methanol, sodium carbonate, Folin-Ciocalteu reagent, Gallic acid, ethanol, DPPH, ascorbic acid, $\mathrm{FeCl}_{3}, \mathrm{H}_{2} \mathrm{O}_{2}$ were purchased analytical grade from Merck (Germany). Plasmid PB322 was purchased from Fermentas Company (Canada).

Plant material: This preparation was carried out in greenhouse and farm of Plant Improvement and Seed Production Research Center (PISPRC), Isfahan (Khorasgan) Branch of Islamic Azad University. After cultivation of seeds (in Isfahan experimental farm $32^{\circ} 38^{\prime} 27.6^{\prime \prime} \mathrm{N}, 51^{\circ} 46^{\prime} 50.3^{\prime \prime} \mathrm{E}$, Iran), the mature bulbs of Yellow \& White Sweet Spanish were harvested. The prepared samples were refrigerated at $4^{\circ} \mathrm{C}$ prior to biochemical analyses. Onions were washed under tap water for a few times to ensure the removal of soil and additional parts. After removing the dry skin (tunic), onion bulbs were peeled to two different depths by (i) the 3 th scales from the outside as outer sample (ii) after removing two scales, the rest of scales as inner sample (5). Peeled bulbs were subjected to extraction methodology.

Preparation of aqueous extraction: The extract methodology was carried out according to Santas et al. (12) with a few modifications. After filtering the aqueous medium with Wathman filter paper NO.2, the filtrates were dried in freeze-dryer (Dena vacuum, Iran). The powder was then stored at $4{ }^{\circ} \mathrm{C}$ in a dark glass.

\section{Chemical analysis}

Total phenol content: The total phenol content of each extract (TP) was determined by the Folin Ciocalteu method as described previously by Singleton and Rossi (13). Values were determined from a calibration curve prepared with Gallic acid $\left(\mathrm{R}^{2}=0.9802\right)$. Results are expressed mean $\pm \mathrm{SD}$ in $\mathrm{mg}$ of Gallic acid per $\mathrm{g}$ of dry weight (mg Gallic acid. ${ }^{-1}$ D.W)

Flavonoid content: Flavonoid content was determined as described by Krizek et al. (14) with a few modifications. Results are expressed as mean \pm SD in $\mathrm{mg}$ flavonoid per $\mathrm{g}$ of dry weight (mg. $\mathrm{g}^{-1}$ D.W) (14).

Radical scavenging activities on DPPH: The free radical scavenging activity of the extract was measured using DPPH by the method of Oliveria et al. Onion extract (50 $\mu \mathrm{l})$ was added to the methanol solution of DPPH. After incubation in the dark and room temperature (30 min), the optical absorption of the samples as read during the $517 \mathrm{~nm}$ by spectrophotometry (UNICO, S2100, USA) against the control sample (15).

DNA nicking assay: The ability of plant extract to protect supercoiled PB322 plasmid DNA from harmful effects of hydroxyl radicals produced by Fenton's regent was 
conducted by DNA protection activity assay as described by Lee et al. with a few modification (16). A reaction mixture containing different bulbs layers treatments (outer and inner layers) and marked plasmid was incubated for 10 min at room temperature, followed by the addition of Fenton's regent. The reaction mixture was then incubated for $30 \mathrm{~min}$ at $37 \mathrm{C}$ and the DNA was analyzed on a $1 \%$ agarose gel.

\section{Antimicrobial activity}

Microorganisms: The antimicrobial activity of extracts was evaluated against the following strain microorganisms were provided as culture by the Iranian Scientific and Industrial Research Organization (IROST) (Tehran, Iran); Bacillus cereus (PTTC 1015 ), Staphylococcus aurus (PTCC 1113), Lactobacillus casei (PTCC 1608), Escherichia coli (PTCC 1399), Salmonella typhimurium (PTCC 1709), Enterococcus faecalis (PTCC 1339), Pseudomonas aeruginosa (PTCC 1310), Monascuspurpureus (PTCC 5303), Aspergillusniger (PTCC 5010), Saccharomyces cerevisiae (PTCC 5269), and Candida albicans (PTTC 5027). Stock cultures were maintained at $4{ }^{\circ} \mathrm{C}$.

Disk diffusion assay: Powder of onion extracts were dissolved in water $(30 \mathrm{mg} / \mathrm{ml})$ and sterilized by filtrating through $0.45 \mu \mathrm{m}$ Millipore filters. Its antimicrobial capacity was evaluated by disc diffusion method (17). Then, a suspension of the tested organism $\left(10^{6} \mathrm{CFU} / \mathrm{ml}\right)$ was spread on the Muller Hinton and Potato Dextrose agar petri plates. Wells (6 $\mathrm{mm}$ in diameter) were impregnated with $100 \mu \mathrm{l}$ extract. The sterile water was also used as the negative control and Levofloxacin $(0.3 \mathrm{mg} / \mathrm{ml})$ and Ketoconazole $(0.2 \mathrm{mg} / \mathrm{ml})$ were used as positive control for bacteria and molds. The plates of bacteria and molds inoculated were incubated at $37{ }^{\circ} \mathrm{C}$ for $48 \mathrm{~h}$ and $28{ }^{\circ} \mathrm{C}, 24 \mathrm{~h}$ for molds and yeasts. The antimicrobial activity was evaluated by measuring the inhibition zone $(\mathrm{mm})$ against the tested microorganism (17).
Micro-well dilution assay: The minimum inhibitory concentration (MIC) of onion extracts were determined by broth dilution method (18). Inoculants $(2 \mu \mathrm{l})$ was dispensed in to the broth media $(500 \mu \mathrm{l})$ which contain $500 \mu \mathrm{l}$ sterilized onion extract and incubated for $24 \mathrm{~h}$ at $37{ }^{\circ} \mathrm{C}$ for bacteria, and at $28{ }^{\circ} \mathrm{C}$ for yeasts and molds. The sterile water was also used as the negative control and Levofloxacin $(0.3 \mathrm{mg} / \mathrm{ml})$ and Ketoconazole $(0.2 \mathrm{mg} / \mathrm{ml})$ were used as positive. The MIC value was determined as the lowest concentration of the sample at which the tested microorganism did not demonstrate any visible growth after incubation. MIC was determined at the lowest concentration where no growth was observed. To determination of minimum microbicidal concentration (MMC) of onion extracts the Canillac et al. (2001) method was used. The samples showing no increases in turbidity were streaked on nutrient agar medium and incubated for $24 \mathrm{~h}$ at $37{ }^{\circ} \mathrm{C}$ for bacteria, $24 \mathrm{~h}$ at $28{ }^{\circ} \mathrm{C}$ for yeasts and molds. The lowest concentration in the nutrient agar which had fewer than three colonies was taken as the MMC (18).

Statistical analysis: The results of all experiments were analyzed based on the experiment in a completely randomized design in three replications. Analysis of variance was performed by SAS (Ver. 9) software and mean comparisons were assayed by an LSD (Least Significant Differences) test at $\mathrm{p} \leq 0.05$.

\section{Results}

Antioxidant activity: The total phenolic contents (TP), flavonoid content of aqueous extracts of the outer/inner layers of onions (Yellow and White Sweet Spanish hybrids) are presented in Table 1. The aqueous extract of the outer layers of White Sweet Spanish onion showed the highest phenol content $(13.62 \pm 0.002 \mathrm{mg}$ GAE /g D.W $)$ and flavonoid content $(0.489 \pm 0.002 \mathrm{mg} / \mathrm{g}$ D.W $)$ $(p<0.05)$. However, inner layers of White and Yellow Sweet Spanish hybrids showed the lowest total phenolic $(9.52 \pm 0.002 \mathrm{mg}$ GAE $/ \mathrm{g}$ D.W $)$ and flavonoid content $(0.43 \pm 0.003 \mathrm{mg} / \mathrm{g} \mathrm{D} . \mathrm{W})$ respectively $(p<0.05)$.

Table 1. Total phenolic contents, flavonoid content and antioxidant capacity f aqueous extracts of inner layers of Yellow and White Sweet Spanish hybrids (Allium cepa L.)

\begin{tabular}{|c|c|c|c|c|}
\hline Landraces & Layers & $\begin{array}{l}\text { Total phenolic contents } \\
(\mathrm{mg} \mathrm{GAE} / \mathrm{g} \mathrm{DW})\end{array}$ & Antioxidant capacity (\%) & $\begin{array}{c}\text { Flavonoid content } \\
(\mathrm{mg} / \mathrm{g} \mathrm{DW})\end{array}$ \\
\hline \multirow{2}{*}{ White Sweet Spanish } & Inner & $9.52^{\mathrm{d}} \pm 0.026$ & $23.03^{\mathrm{b}} \pm 0.001$ & $0.479^{\mathrm{b}} \pm 0.035$ \\
\hline & Outer & $13.325^{\mathrm{a}} \pm 0.020$ & $23.93^{\mathrm{a}} \pm 0.001$ & $0.489^{\mathrm{a}} \pm 0.025$ \\
\hline \multirow{2}{*}{ Yellow Sweet Spanish } & Inner & $11.692^{c} \pm 0.020$ & $21.1^{\mathrm{d}} \pm 0.017$ & $0.432^{\mathrm{c}} \pm 0.036$ \\
\hline & Outer & $12.52^{\mathrm{b}} \pm 0.023$ & $22.13^{\mathrm{c}} \pm 0.002$ & $0.489^{\mathrm{a}} \pm 0.037$ \\
\hline
\end{tabular}

Different letters in each Colum indicate significant differences in means at $\mathrm{P}<0.05$. 
The results of DPPH free radical scavenging ability of aqueous extracts of the outer/inner layers of onions were shown in Table 1. The DPPH free radical scavenging ability of extract of outer layers of White Sweet Spanish onion was the highest $(23.9 \% \pm 0.001)$ and of inner layers of Yellow Sweet Spanish was the lowest $(21.1 \% \pm 0.001)$ $(p<0.05)$.

In evaluation of biological activity, the DNA nicking assay as a powerful tool that can be used to estimate the extract antioxidant effects (5).The effect of extracts on the protection of DNA damage was shown in Fig 1. With the creation of hydroxyl ions, Fenton's reagent has caused plasmid damage and converts the supercoil form into a linear, and the extract of the onion containing phenolic contents can be prevented by forming a bond with hydroxyl ions from the plasmid damage and the shape of changes in the gel electrophoresis is visible. With comparison of lane 1 to 4 with control (lane $5 \& 6$ ) can be understood that the outer layer of Yellow Sweet Spanish onion extract has a more inhibitory effect on the hydroxyl radical produced from Fenton s regent also inner layers of White Sweet Spanish onion extract has less inhibitory effect.

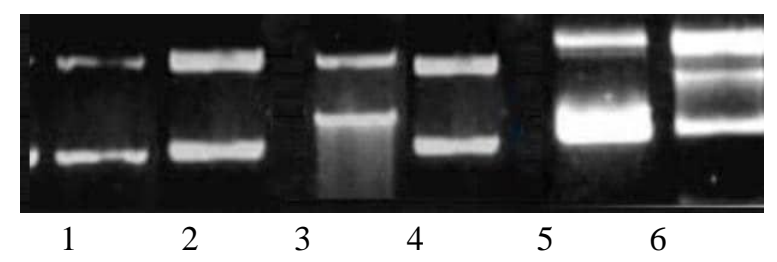

Fig. 1. Inhibitory effects of onion extracts on DNA nicking caused by hydroxyl radicals. Lane 1, outer layers of Yellow Sweet Spanish extract; lane 2, Inner layers of Yellow Sweet Spanish; lane 3, outer layers of White Sweet Spanish extract; lane 4, inner layers of White Sweet Spanish extract; lane 5, Fenton's regent + DNA; lane 6, native PB322 DNA.
Antimicrobial activity: The antimicrobial activity of aqueous extracts of inner layers of Yellow and White Sweet Spanish (Allium cepa L.) were evaluated by measuring the inhibition zone against the microorganism. The results showed (data was not shown) the aqueous extracts of outer layers of Yellow and White Sweet Spanish hybrids had no antimicrobial effect. The results of antimicrobial activity of aqueous extracts are presented in Table 2. Yellow Sweet Spanish onion showed a higher inhibition zone than White Sweet Spanish one in disk diffusion assay. The inhibition zone of Yellow Sweet Spanish onion was higher significantly than Whit Sweet Spanish one against the positive, negative gram bacteria, mold and yeast $(p<0.05)$. However, the sensitivity of yeasts and mold had higher significantly than bacteria and positive gram bacteria had higher than negative gram bacteria against aqueous extracts of outer layers of onions $(p<0.05)$.

The MIC and MMC of aqueous extracts of inner layers of onions (Yellow and White Sweet Spanish) were showed in Table 3. The MIC and MMC of Yellow Sweet Spanish hybrids extract were (15 to $25 \mathrm{mg} / \mathrm{ml}$ ) and (20 to 30 $\mathrm{mg} / \mathrm{ml}$ ) against gram positive bacteria and (15 to 25 $\mathrm{mg} / \mathrm{ml}),(20-30 \mathrm{mg} / \mathrm{ml})$ against gram negative bacteria which is lower concentration compared to with White Sweet Spanish extract (20 to $30 \mathrm{mg} / \mathrm{ml}$ ), (25 to $30 \mathrm{mg} / \mathrm{ml}$ ), (25 to $30 \mathrm{mg} / \mathrm{ml}$ ) and $(25$ to $30 \mathrm{mg} / \mathrm{ml})$ respectively. The MIC and MMC of Yellow and White Sweet Spanish extract had the similar effects against yeast and mold. Results showed the extract of onion had more inhibitory effect on molds and yeasts in comparison to bacteria. Also the gram positive bacteria more sensitive than gram negative bacteria.

Table 2. The antimicrobial activity of aqueous extracts of inner layers of onions (Yellow and White Sweet Spanish) on diameter of zone of inhibition (mm)

\begin{tabular}{|c|c|c|c|c|}
\hline \multirow{2}{*}{\multicolumn{2}{|c|}{ Microorganism }} & \multicolumn{3}{|c|}{ Diameter of zone of Inhibition (mm) } \\
\hline & & \multicolumn{2}{|c|}{ Sweet Spanish } & \multirow[t]{2}{*}{ Control } \\
\hline & & White & Yellow & \\
\hline \multirow{3}{*}{ Positive gram bacteria } & Bacillus cereus & $1.93^{b} \pm 0.11$ & $3.1^{\mathrm{a}} \pm 0.11$ & 9.8 \\
\hline & Staphylococcus aurus & $1.9^{\mathrm{b}} \pm 0.1$ & $2.7^{\mathrm{a}} \pm 0.2$ & 21 \\
\hline & Lactobacillus casei & $0^{\mathrm{b}}$ & $1.16^{\mathrm{a}} \pm 0.25$ & 3 \\
\hline \multirow{4}{*}{ Negative gram bacteria } & Escherichia coli & $0^{\mathrm{b}}$ & $1.3^{\mathrm{a}} \pm 0.2$ & 10 \\
\hline & Salmonella typhimurium & $1.93^{\mathrm{b}} \pm 0.11$ & $2.43^{\mathrm{a}} \pm 0.2$ & 5.5 \\
\hline & Enterococcus faecalis & $2.1^{\mathrm{b}} \pm 0.17$ & $2.43^{\mathrm{a}} \pm 0.2$ & 5 \\
\hline & Pseudomonas aeruginosa & $0^{\mathrm{b}}$ & $0.6^{\mathrm{a}} \pm 0.1$ & 7.2 \\
\hline \multirow[t]{2}{*}{ Molds } & Monascuspurpureus & $13.66^{\mathrm{b}} \pm 1.52$ & $14^{\mathrm{a}} \pm 025$ & 11 \\
\hline & Aspergillusniger & $1.13^{\mathrm{b}} \pm 0.11$ & $1.46^{\mathrm{a}} \pm 0.1$ & 17 \\
\hline \multirow[t]{2}{*}{ Yeasts } & Saccharomyces cerevisiae & $20^{\mathrm{b}} \pm 2$ & $24^{\mathrm{a}} \pm 1.73$ & 26 \\
\hline & Candida albicans & $1^{\mathrm{b}} \pm 0.3$ & $1.03^{\mathrm{a}} \pm 0.25$ & 3.4 \\
\hline
\end{tabular}

Different letters in each Colum indicate significant differences in means at $\mathrm{P}<0.05$ 
Table 3. The minimum inhibitory concentration (MIC) (mg/ml) and minimum microbicidal concentrations (MMC) (mg/ml) of aqueous extracts of inner layers of onion (Yellow and White Sweet Spanish)

\begin{tabular}{|c|c|c|c|c|c|c|c|}
\hline \multirow{3}{*}{\multicolumn{2}{|c|}{ Microorganism }} & \multicolumn{3}{|c|}{$\mathrm{MIC}(\mathrm{mg} / \mathrm{ml})$} & \multicolumn{3}{|c|}{$\mathrm{MMC}(\mathrm{mg} / \mathrm{ml})$} \\
\hline & & \multicolumn{2}{|c|}{ Sweet Spanish } & \multirow{2}{*}{ Control } & \multicolumn{2}{|c|}{ Sweet Spanish } & \multirow{2}{*}{ Control } \\
\hline & & White & Yellow & & White & Yellow & \\
\hline Positive gram & Staphylococcus aurus & 20 & 15 & 0.1 & 25 & 20 & 0.15 \\
\hline \multirow[t]{2}{*}{ bacteria } & Lactobacillus casei & 30 & 25 & 0.25 & 30 & 30 & 0.25 \\
\hline & Escherichia coli & 30 & 15 & 0.2 & 30 & 20 & 0.25 \\
\hline \multirow{2}{*}{$\begin{array}{c}\text { Negative gram } \\
\text { bacteria }\end{array}$} & Enterococcus faecalis & 30 & 25 & 0.3 & 30 & 30 & 0.3 \\
\hline & Pseudomonas aeruginosa & 30 & 20 & 0.25 & 30 & 30 & 0.3 \\
\hline \multirow[t]{2}{*}{ Molds } & Monascuspurpureus & 7 & 6 & 0.15 & 10 & 7 & 0.2 \\
\hline & Aspergillusniger & 15 & 15 & 0.15 & 20 & 20 & 0.2 \\
\hline Yeasts & Saccharomyces cerevisiae & 6 & 6 & 0.05 & 7 & 6 & 0.1 \\
\hline
\end{tabular}

\section{Discussion}

Antioxidant activity: Quercetin and kaempherol and their glycosides are the most abundant content of flavonoids in the onion has been reported (19). There are many reports that have examined the importance of skin and non-edible parts of vegetables as phenolic source including skin of onion (20). Bilyk et al. found that the skin of onions had more phenolic content, quercetin in form aglycone and glycoside than the edible part. All quercetin content in onions are available in a free form in colored onion rings $(21,22,23)$. Results are in good agreement with recent publication where flavonoid and phenolic content in edible part of yellow onion variety were higher than white onion varieties $(5,24)$. Many publications are present that showed the phenolic and flavonoid content in outer layer of red and yellow onions were higher than inner layers of white onions $(5,23)$. For example, the highest total phenolic was in outer layers of red onion (74.1 mg / g GAE) and this value was $5.6 \mathrm{mg} / \mathrm{g} \mathrm{GAE}$ for inner layers of red onion, also total phenolic was $7.4 \mathrm{mg} / \mathrm{g}$ GAE for outer layers of white inion and $5.4 \mathrm{mg} / \mathrm{g}$ GAE for inner layers of white onion (5). The effect of antioxidant on DPPH radical scavenging was conceived to their hydrogen ability (15). In current study the phenolic and flavonoid contents and DPPH free radical scavenging ability of extract of outer layers of onions were higher than inner layers. The outer layers of onions had highest antioxidant activity. Recent publication showed flavonoid and phenolic compounds were mainly present in the ethyl acetate subfraction but represented only a small percentage of total phenol present in the aqueous subfraction $(12,25)$.

The hydroxyl radicals generated from Fenton's regent is effective on the DNA and leads to the opening of supercoils form of plasmid. The phenolic content of extract onion by creating a link with hydroxyl radical prevents its effect on DNA. In fact, the phenolic content protect the plasmid from oxidative damage; oxidative damage to biomolecular, such as nucleic acids, causese several diseases such as cancer. In this research, the effect of the protection of phenolic content of onion extracts from the oxidative damage of hydroxyl radical was compared (5). The outer layers have the most radical inhibitory properties and also the most antioxidant property in front of the hydroxyl radical showed (Fig 1). However, this test is a qualitative method for examining the antioxidant properties of the extracts, but it is good to show the antioxidant advantage of outer layers of onion in the cell system and on the structure of the nucleic acids.

Antimicrobial activity: In the present study, the aqueous extracts of outer layers of Yellow and White Sweet Spanish hybrids had no antimicrobial effect. However, extracts of inner layers onions inhibited the growth of some important bacteria and fungi that which showed the effect of organosulfur compounds in onions as antimicrobial property. Sulfur compounds cause antimicrobial activity in onions. These compounds are lost due to volatility in the outer layers. Therefore, the inability of the outer layers of the onion to kill the bacteria can be due to the loss of sulfur compounds in them. (12). Sulfuric content in onions including various types of thiosulfinate, are mainly responsible for the antimicrobial effects. In addition, flavonoids, phenolic content, some proteins can also cause antimicrobial activity. The results showed that the aqueous extract of Yellow Sweet Spanish hybrids had more antimicrobial activity than White Sweet Spanish hybrids. Many publications have reported that flavonoids had antimicrobial activity (12). Extract of both onions had more inhibitory effects on molds and yeasts than bacteria. Also the gram positive was more sensitive than gram negative bacteria. These results are in good agreement with recent publications that gram negative bacteria such as Escherichia coli, Salmonella typhimuriumdue to the lipopolysaccharide coating layer is resistant to gram positive bacteria such as Bacillus cereus, Staphylococcus aureus, Lactobacillus casei (12). The thiosulfinates of onion extract is effective on microorganisms, in fact, the sulfur dye group is combined with cell protein and breaks 
the cell wall of microorganism (26). Although the sulfur compounds such as thiosulfinates are unstable antimicrobial agents in the onion, phenolic content is also regarded as an effective component of onion on microorganism such as flavonoids, which are more stable (27). Onions are as a good source of phenolic compounds in this opinion can be raised in addition to the antioxidant property crushed as a good antimicrobial compounds (28).

\section{Conclusion}

The Yellow Sweet Spanish and White Sweet Spanish onion are two common onion cultivated and consumed in Isfahan farms $32^{\circ} 38^{\prime} 27.6^{\prime \prime} \mathrm{N}, 51^{\circ} 46^{\prime} 50.3^{\prime \prime} \mathrm{E}$, Iran, which show promising use as a natural compounds with antibacterial, antioxidant and antifungal. Our data indicate that aqueous extracts of Yellow and White Sweet Spanish onion shows a moderate antimicrobial activity against referenced strains and also possess an interesting antioxidant activity. Yellow Sweet Spanish hybrids had more antioxidant properties than White Sweet Spanish hybrids. The extract of inner layers of Yellow Sweet Spanish hybrids had more inhibitory effect against referenced strains. Taken together, these results show that the aqueous extracts of Yellow and White Sweet Spanish onion could be considered as a natural alternative to traditional food preservatives and be used to enhance food safety and shelf life.

\section{Financial disclosure}

The authors declared no financial interest

\section{Funding/Support}

This research did not receive any specific grant from funding agencies in the public, commercial, or not-forprofit sectors.

\section{References}

1.Rose P, Whiteman M, Moore P K \& Zhu Y Z. Bioactive Salk(en)yl cysteine sulfoxide metabolites in the genus Allium: the chemistry of potential therapeutic agents. Journal of Natural Product Reports. 2005; 22 (3): 351-368.

2. Keighobadi K, Golabadi M, Khozaei M, Rezai A. Screening of factors affecting somatic callusing and embryo induction in Allium cepa L. through Placket-Burman methodology. Turkish Journal of Agriculture and Forestry. 2020; 44 (doi:10.3906/tar-1905-43).

3. Marrelli M, Amodeo V, Statti G and Conforti F. Biological Properties and Bioactive Components of Allium cepa L.: Focus on Potential Benefits in the Treatment of Obesity and Related Comorbidities. Molecules. 2019; 24 (119): 2-18.

4. Lourenço S C , Moldão-Martins $M$ and Alves V D. Antioxidants of Natural Plant Origins: From Sources to Food Industry Applications. Molecules. 2019; 24 (4132): 1-25.

5.Prakash D, Singh BN, Upadhyay G. Antioxidant and free radical scavenging activities of phenols from onion (Allium cepa L.). Food Chemistry. 2007; 102:1389-1393.

6. Mahdi-Pour B, Jothy S L, Yoga Latha L, Chen Y, Sasidharan S. Antioxidant activity of methanol extracts of different parts of Lantana camara. Asian Pacific Journal of Tropical Biomedicine. 2012; 2(12): 960-965.

7. Sharifi-Rad J,Hoseini-Alfatemi S M,Sharifi-Rad M,Teixeira da Silva J A. Antibacterial, antioxidant, antifungal and antiinflammatory activities of crude extract from Nitrariaschoberi fruits. 3Biotech. 2015; 5:677-684.

8. Kosmider B \&Osiecka R. Flavonoid compounds: A review of anticancer properties and interaction with cisdiamminedichloroplatinum (II). Drug Development Research. 2004; 63: 200-211

9. Lin Ye C, Hui Dai D, Lian Hu W. Antimicrobial and antioxidant activities of the essential oil from onion (Allium cepa L.). Food Control. 2013; 30: 48- 53.

10. Benkeblia N. Antimicrobial activity of essential oil extracts of various onions (Allium cepa L.) and garlic (Allium sativum). Brazilian Archives of Biology and Technology. 2004; 37:263268.

11. Augusti K, Mathew T. Lipid lowering effect of allicin (diallyldisulphide-oxide) on long term feeding to normal rats. Cellular and Molecular Life Sciences. 1974; 30(5): 468-47.

12. Santas J, Almajano MP \&Carbó R. Antimicrobial and antioxidant activity of crude onion (Allium cepa L.) extracts. International Journal of Food Science \& Technology. 2010; 45(2): 403-409.

13. Singleton VL, Rossi JA. Colorimetry of total phenolics with phosphomolybdic phosphotungstric acid reagents. American Journal of Enology and Viticulture. 1965; 16: 144-158.

14. Krizek D T, Britz S J \&Mirecki RM. Inhibitory effects of ambient levels of solar UV-B radiation on growth cv. New Leaf Fire lettuce. Physiologia Plantarum. 1998; 103: 1-7.

15. Oliveira G K F, Sousa R M F, Morais S A L d, \&Muno R A A. Batch-injection analysis with amperometric detection of the DPPH radical for evaluation of antioxidant capacity. Food Chemistry. 2016; 192(1): 691-697.

16. Lee C J, Lee J T, Kwor J H, Kim B C, \& Park W. Occurrence of bacterial soft rot of onion plants caused by Burkholderiagladiolipv. alliicola in Korea. Australasian PlantPathology.2005; 34(3): 287-292.

17. Lastovica AJ, Dewet PM, Rode H, Sidler D.Allicin a possible answer to antibiotic resistant campylobacter diarrhoeal infection. Archives of Disease in Childhood. 1999; 81:278.

18. Canillac $\mathrm{N}$ and Mourey A. Antibacterial activity of the essential oils of Piceaexcelsa on Listeria monocytogenes, Staphylococcus aureus and coliform bacteria. Food Microbiology. 2001; 18: 261-268.

19. Chu Y H, Chang C L, Hsu H F. Antioxidant capacity of tea and common vegetable and their antioxidant activity. Journal of the Science of Food and Agriculture. 2000; 80: 561- 566.

20. Kallel F, Driss D, Chaari F, Belghith L, Bouaziz F, Choebel R, Chaabouni S E. Garlic (Alliumsativum L.) husk waste as a potential source of phenolic compounds: Influence of extracting solvents on its antimicrobial and antioxidant properties. Industrial Crops and Products. 2014; 62: 34- 41.

21-Bilyk A Cooper P L, Sapers G M. Varietal differences in distribution of quercetin and kaempferol in onion (Allium сера) tissue. Journal of Agricultural and Food Chemistry. 1984; 32: 274-276.

22. Patil B S \& Pike L M. Distribution of quercetin content in different rings of various coloured onion (Allium cepa L.) cultivars. Journal of Horticultural Science. 1995; 70: 643-650. 
23. Nuutila A M, Kammiovirta K, Oksman-Caldentey K M. Comparison of methods for the hydrolysis of flavonoids and phenolic acids from onion and spinach for HPLC analysis. Food Chemistry. 2002; 76: 519-525.

24. Sellappan S, Akoh CC. Flavonoids and antioxidant capacity of Georgia-Grown Vidalia onions. Agriculture Food Chemistry. 2002; 50: 5338-42.

25. Singh B N, Singh B R, Singh R L. Polyphenolics from various extracts/fraction of red onion (Allium cepa) peel with potent antioxidant and antimutagenic activities. Food and Chemical Toxicology. 2009; 42, 1161-1167.
26. Fujisawa H, Watanable K, Suma K, Origuchi K, Matsufuji H, Seki T, Ariga T. Antibacterial potential of garlic-derived allicin and its cancellation by sulfhydryl compounds. Bioscience Biotechnology Biochemistry. 2009; 73: 19481955.

27. Ioku K, Aoyama Y, Tokuno J, Nakatani N, Takei Y. Various cooking methods and the flavonoid content in onion. Nutritional Science and Vitaminology. 2001; 47: 78-83.

28. Fossen T, Pedersen A T \& Andersen O M. Flavonoids from red onion (Allium cepa). Photochemistry. 1998; 47: 281-285. 